\title{
Prevalensi kasus dehidrasi pada mahasiswa Universitas Gadjah Mada
}

The prevalence of dehydration among students of Gadjah Mada University

Mirza Hapsari Sakti Titis Penggalih ${ }^{1}$, Zaenal Mutaqien Sofro ${ }^{2}$ Eka Roshifita Rizqi ${ }^{1}$, Yuniko Fajri ${ }^{1}$

\begin{abstract}
Background: Involuntary dehydration can lead to body function of disturbances. Orthostatic measurements were performed to determine the involuntary dehydration caused by orthostatic hypotension. Dehydration is also influenced by the high level of activity and ambient temperature without sufficient fluid intake. Students are prone to dehydration due to their activity, they have to be well hydrated to achieve their academic and non academic performances. Objective: To determine the prevalence of dehydration among students of Gadjah Mada University. Method: An observasional study with cross sectional design were conducted and involved 274 student of Gadjah Mada University. Orthostatic measurement and interview of their activity and smoking habit were performed on all subjects. Results: The prevalence of dehydration were 60.9\%. Type of activity and smoking habit did not effect the hydration status. Conclusion: Dehydration prevalence rate is still high on the students. As almost all students are dehydrated, then the factors that should be able to distinguish the condition of dehydration such as type of activity and smoking habit, seems to give no effect in this study.
\end{abstract}

KEY WORDS: dehydration, orthostatic, students

\begin{abstract}
ABSTRAK
Latar belakang: Dehidrasi yang tidak disadari dapat mengakibatkan gangguan pada tubuh. Pengukuran ortostatik dilakukan untuk mengetahui dehidrasi yang tidak disadari melalui adanya kondisi hipotensi ortostatik. Dehidrasi juga dipengaruhi oleh tingkat aktivitas dan suhu lingkungan yang tinggi tanpa didukung oleh asupan cairan yang cukup. Mahasiswa harus memiliki status hidrasi yang baik agar dapat mendukung performa mahasiswa. Tujuan: Penelitian ini dilakukan untuk mengetahui prevalensi dehidrasi pada mahasiswa di Universitas Gadjah Mada. Metode: Penelitian ini merupakan penelitian deksriptif analitik dengan pendekatan obervational dan desain cross sectional. Sebanyak 274 mahasiswa UGM yang memenuhi kriteria inklusi dilakukan pengukuran ortostatik untuk mengetahui dehidrasi. Faktor seperti jenis kegiatan mahasiswa dan kebiasaan merokok dikaji dengan wawancara. Hasil: Prevalensi involuntary dehydration pada mahasiswa UGM adalah 60,9\%. Lebih lanjut diketahui bahwa jenis aktivitas dan kebiasaan merokok tidak mempengaruhi status hidrasi $(\mathrm{p}>0,05)$. Simpulan: Angka prevalensi dehidrasi pada mahasiswa masih tinggi. Oleh karena itu, hampir semua mahasiswa mengalami dehidrasi, maka faktor yang seharusnya dapat membedakan kondisi dehidrasi seperti jenis kegiatan dan kebiasaan merokok, tidak memberikan pengaruh pada penelitian ini.
\end{abstract}

KATA KUNCI: dehidrasi, ortostatik, mahasiswa

\section{PENDAHULUAN}

Ketidakseimbangan cairan tubuh dapat mengakibatkan terjadinya dehidrasi. Dehidrasi merupakan kondisi di saat tubuh kekurangan banyak cairan. Dehidrasi dapat terjadi karena adanya pengaruh kondisi lingkungan atau cuaca, misalnya pada saat kondisi udara panas maka tubuh akan mengeluarkan keringat yang cukup banyak dan dapat mengakibatkan dehidrasi. Penelitian lain menunjukkan bahwa terdapat $48 \%$ orang dewasa mengalami dehidrasi dan $26 \%$ diantaranya tidak menyadari hal tersebut (1). Sedangkan di Indonesia, berdasarkan penelitian yang dilakukan pada tahun 2009 didapatkan prevalensi kasus dehidrasi pada remaja dan dewasa sebesar $46,1 \%$. Hasil penelitian tersebut menunjukkan bahwa jumlah remaja yang mengalami dehidrasi ringan lebih tinggi dibandingkan dewasa yaitu $49,5 \%$ untuk remaja dan $42,5 \%$ pada dewasa (2).

\footnotetext{
Korespondensi: Program Studi S1 Gizi Kesehatan, Fakultas Kedokteran Universitas Gadjah Mada, Jl. Farmako Sekip Utara Yogyakarta, 55281, Telp/ Fax 0274-547775,e-mail: mirza hapsari@yahoo.com

2 Bagian Fisiologi, Fakultas Kedokteran Universitas Gadjah Mada, Jl. Farmako Sekip Utara Yogyakarta, 55281
} 
Kondisi dehidrasi yang berkelanjutan dapat mengakibatkan pengentalan pada sirkulasi darah sehingga dapat menyebabkan gangguan fungsi organ. Dehidrasi yang tidak disadari disebut juga sebagai involuntary dehydration. Kondisi involuntary dehydration merupakan kondisi dehidrasi atau defisit cairan yang terjadi ketika sensasi haus tidak cukup kuat untuk merangsang seseorang mengonsumsi minuman dalam jumlah yang cukup sehingga tidak dapat menggantikan kehilangan air secara cepat. Kondisi dehidrasi akan mempengaruhi keadaan tekanan darah dan denyut jantung apabila diukur melalui pengukuran ortostatik. Pengukuran ortostatik dilakukan untuk mengetahui kondisi dehidrasi yang tidak disadari yaitu dengan melihat apakah terdapat penurunan tekanan darah sistolik hingga $20 \mathrm{mmHg}$ atau diastolik sebesar $10 \mathrm{mmHg}$ (3). Kondisi tersebut juga dapat dilihat dari adanya peningkatan denyut jantung lebih dari 120 denyut per menit ketika seseorang berganti posisi dari berbaring ke berdiri. Peningkatan denyut jantung akan disertai dengan peningkatan cardiac output dan penurunan stroke volume. Adanya penurunan tekanan darah pada pengukuran ortostatik disebut hipotensi ortostatik. Penyebab utama dari hipotensi ortostatik adalah dehidrasi (4).

Kejadian dehidrasi dapat diakibatkan faktor cuaca atau kondisi suhu lingkungan yang panas, karena lingkungan dengan udara panas dapat mengakibatkan keluarnya keringat dalam jumlah yang cukup banyak (5). Indonesia merupakan salah satu negara dengan iklim tropis sehingga suhu di Indonesia cukup tinggi. Selain pengaruh suhu, tingkat aktivitas yang dilakukan oleh seseorang juga akan mempengaruhi kehilangan cairan tubuh. Setiap orang memiliki tingkat aktivitas yang bermacam-macam termasuk mahasiswa. Selain dituntut untuk mencapai prestasi akademik yang baik, seorang mahasiswa juga dihadapkan dengan berbagai pilihan kegiatan pengembangan diri yang semuanya menuntut kondisi fisik yang prima. Kondisi fisik yang prima dapat dipenuhi dengan kondisi hidrasi tubuh yang baik. Oleh karena itu perlu dilakukan identifikasi kondisi hidrasi tersebut di tingkat mahasiswa di Universitas Gadjah Mada (UGM).

\section{BAHAN DAN METODE}

Penelitian ini adalah penelitian observasional dengan desain penelitian cross sectional yang dilaksanakan pada bulan November - Desember 2012. Penelitian ini mengamati kasus dehidrasi yang diukur dengan uji ortostatik pada mahasiswa UGM. Teknik pengambilan sampel menggunakan cluster sampling yang dapat mewakili seluruh fakultas di Universitas Gadjah Mada. Mahasiswa UGM yang berusia kurang dari 20 tahun dan berjenis kelamin laki-laki dilibatkan dalam penelitian ini. Adapun mahasiswa yang menderita penyakit kronik seperti hipertensi, jantung, dan gagal ginjal dieksklusi dari penelitian ini. Berdasarkan perhitungan sampel diperoleh sampel minimal dalam penelitian ini sebesar 274 orang. Subjek pada penelitian ini adalah 274 mahasiswa UGM yang tersebar di 18 Fakultas yaitu Biologi, Farmasi, Kedokteran (KU), Kedokteran Gigi (KG), Kedokteran Hewan (KH), Kehutanan, Matematika dan Ilmu Pengetahuan Alam (MIPA), Pertanian, Peternakan, Teknik, Teknologi Pertanian (TP), Filsafat, Ekonomi dan Bisnis (FEB), Geografi, Hukum, Ilmu Budaya, Psikologi, dan Ilmu Sosial. Adapun bagan pengambilan sampel mahasiswa dapat dilihat pada Gambar 1.

Dehidrasi diukur dengan melakukan pengamatan ortostatik yaitu dengan mengukur tekanan darah dan denyut jantung yang dilakukan menggunakan alat pengukur tekanan darah digital Omron Model SEM-1. Teknik pengukuran dilakukan dengan memasang arm cuff pada lengan subjek dan bagian air plug pada air tube disambungkan dengan main unit. Bagian main unit adalah unit display hasil pengukuran tekanan darah dan denyut jantung. Pengukuran tekanan darah dan denyut jantung dilakukan pada posisi supine atau berbaring sebanyak 5 kali setiap menit. Setelah 5 kali pengukuran, subjek langsung diminta berdiri atau pada posisi upright sebanyak 7 kali setiap menit. Pengambilan data tekanan darah dan denyut jantung dilakukan oleh enumerator yang sudah terlatih. Kondisi dehidrasi ditentukan dengan melihat selisih antara rata-rata pemeriksaan saat berbaring dengan hasil pengukuran tekanan darah dan denyut jantung saat pemeriksaan pertama pada posisi berdiri. Apabila terjadi penurunan tekanan darah sistolik lebih dari $20 \mathrm{mmHg}$, tekanan darah diastolik $10 \mathrm{mmHg}$, dan atau adanya peningkatan denyut jantung lebih dari 120 beats per minute (bpm) pada posisi berdiri saat dilakukan pengukuran tekanan darah dan denyut jantung maka seseorang dinyatakan mengalami kondisi dehidrasi yang tidak disadari atau involuntary dehydration. Selain 


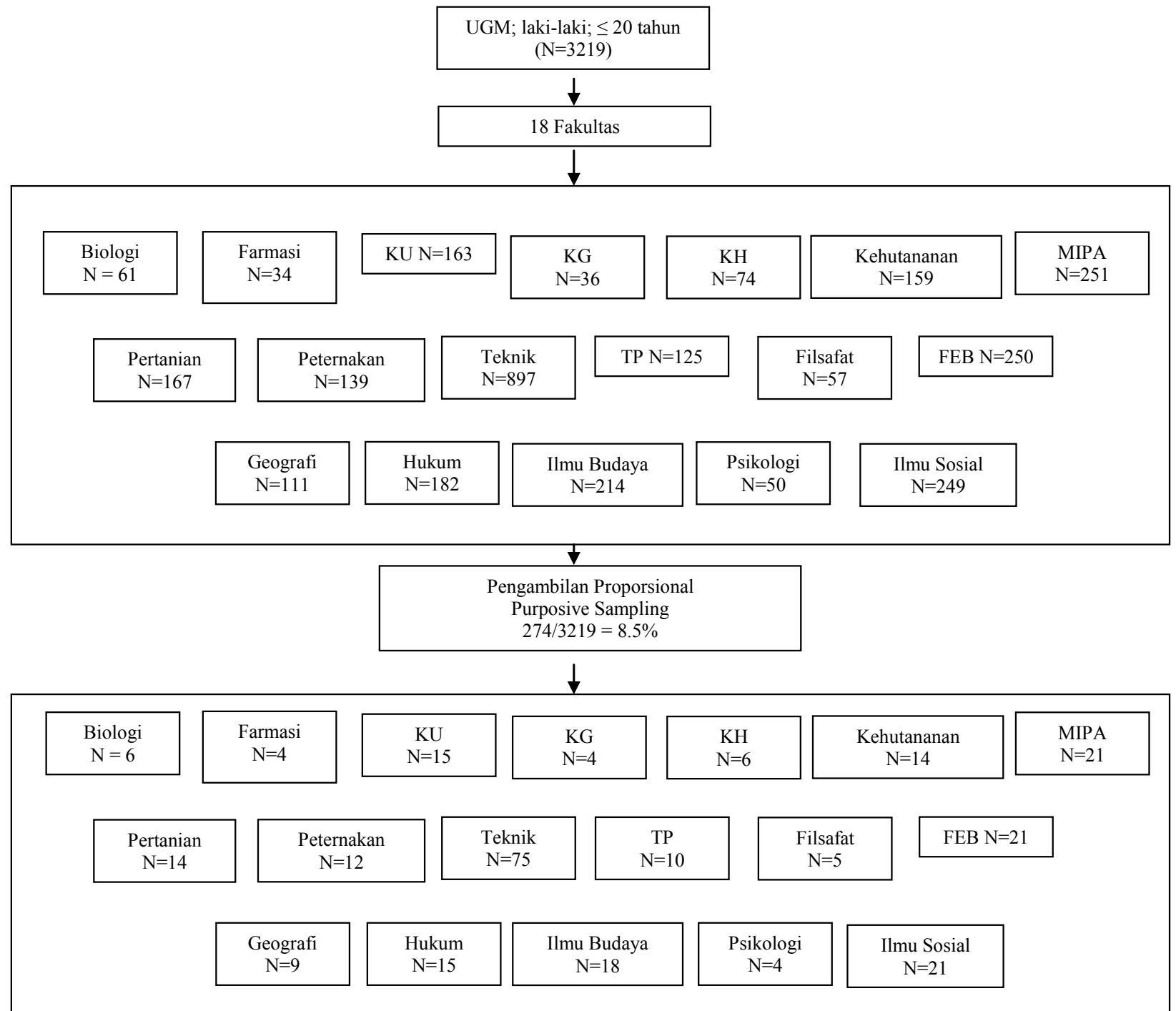

Gambar 1. Alur pengambilan subjek

melakukan pengukuran ortostatik, dalam penelitian ini juga mengkaji aktifivitas mahasiswa di luar kegiatan akademik seperti kegiatan organisasi, olahraga, dan kebiasaan merokok melalui wawancara. Analisis data secara deskriptif analitik digunakan untuk mengambil kesimpulan dalam penelitian ini.

\section{HASIL}

Berdasarkan Tabel 1 diketahui bahwa dari 274 responden, sebagian besar responden mengikuti kegiatan organisasi rutin $(78,1 \%)$, olahraga $(52,6 \%)$, tidak merokok $(86,5 \%)$, dan mengalami dehidrasi $(60,9 \%)$.
Dari variabel-variabel di atas, kemudian dilakukan uji Chi-Square untuk mengetahui hubungan antara variabel dengan kondisi hidrasi. Variabel tersebut adalah umur, kegiatan olahraga, kegiatan organisasi, dan kebiasaan merokok. Berdasarkan Tabel 2 diketahui bahwa tidak ada hubungan antara variabel dengan kondisi hidrasi.

\section{BAHASAN}

Berdasarkan hasil penelitian diketahui bahwa prevalensi dehidrasi yang tidak disadari pada subjek penelitian sebesar $60,9 \%$. Hal tersebut diketahui dari 
Tabel 1. Karakteristik subjek penelitian

\begin{tabular}{lcc}
\hline \multicolumn{1}{c}{ Karakteristik } & n & \% \\
\hline Umur (tahun) & & \\
$\quad 17-18$ & 48 & 17,5 \\
$19-20$ & 226 & 82,5 \\
$\quad$ Total & 274 & 100,0 \\
\hline Kegiatan organisasi & & \\
$\quad$ Ya & 214 & 78,1 \\
$\quad$ Tidak & 60 & 21,9 \\
\hline Total & 274 & 100,0 \\
Kegiatan olahraga & & \\
$\quad$ Ya & 144 & 52,6 \\
\hline Tidak & 130 & 47,4 \\
\hline Total & 274 & 100,0 \\
Merokok & & \\
Ya & 37 & 13,5 \\
\hline Tidak & 237 & 86,5 \\
\hline Total & 274 & 100,0 \\
\hline Hidrasi & & \\
Dehidrasi & 167 & 60,9 \\
\hline Tidak dehidrasi & 107 & 39,1 \\
\hline Total & 274 & 100,0 \\
\hline
\end{tabular}

jumlah subjek yang mengalami hipotensi ortostatik pada saat dilakukan pengukuran. Berbeda dengan penelitian di California yang menemukan $26 \%$ orang dewasa mengalami dehidrasi yang tidak disadari (1). Sementara di Indonesia, prevalensi dehidrasi yang terjadi pada usia remaja akhir adalah 49,5\% (2). Besarnya angka prevalensi kondisi dehidrasi tidak disadari yang terjadi pada subjek penelitian ini dapat diakibatkan oleh beberapa faktor seperti kegiatan atau aktivitas dan suhu lingkungan. Perbedaan hasil penelitian tersebut dapat terjadi karena lokasi dilakukannya penelitian yaitu di California yang memiliki perbedaan iklim dengan Indonesia. Selama berolahraga, pengeluaran cairan tubuh melalui keringat cukup tinggi karena semakin meningkatnya suhu tubuh pada saat beraktivitas. Dalam keadaan seperti ini, ginjal tetap berfungsi menjaga keseimbangan cairan tubuh yaitu dengan cara mengurangi aktivitasnya sehingga urin yang terbentuk lebih sedikit dan lebih pekat. Selain itu, kehilangan cairan yang tidak disadari akibat penguapan akan meningkat 100-150 cc/hari pada kenaikan suhu 1 derajat celcius di atas normal (5).

Golongan umur subjek dalam penelitian ini adalah 17-20 tahun. Rerata remaja pada rentang umur 15-24 tahun tidak mengonsumsi air dalam jumlah yang cukup.
Tabel 2. Hubungan antar variabel dengan kondisi hidrasi

\begin{tabular}{|c|c|c|c|}
\hline \multirow[b]{2}{*}{ Variabel } & \multicolumn{2}{|c|}{ Kondisi hidrasi } & \multirow[b]{2}{*}{$\mathbf{p}$} \\
\hline & $\begin{array}{c}\text { Dehidrasi } \\
\text { n (\%) }\end{array}$ & $\begin{array}{c}\text { Tidak dehidrasi } \\
\text { n (\%) }\end{array}$ & \\
\hline \multicolumn{4}{|l|}{ Umur (tahun) } \\
\hline $17-18$ & $31(18,6)$ & $17(15,9)$ & 0,570 \\
\hline $19-20$ & $136(81,4)$ & $90(84,1)$ & \\
\hline Total & $167(100)$ & $107(100)$ & \\
\hline \multicolumn{4}{|l|}{ Organisasi } \\
\hline Ya & $131(78,4)$ & $83(77,6)$ & 0,865 \\
\hline Tidak & $36(21,6)$ & $24(22,4)$ & \\
\hline Total & $167(100)$ & $107(100)$ & \\
\hline \multicolumn{4}{|l|}{ Olahraga } \\
\hline Ya & $82(49,1)$ & $62(57,9)$ & 0,153 \\
\hline Tidak & $85(50,9$ & $45(42,1)$ & \\
\hline Total & $167(100)$ & $107(100)$ & \\
\hline \multicolumn{4}{|l|}{ Merokok } \\
\hline Ya & $23(13,8)$ & $14(13,1)$ & 0,871 \\
\hline Tidak & $144(86,2)$ & $93(86,9$ & \\
\hline Total & $167(100)$ & $107(100)$ & \\
\hline
\end{tabular}

Rata-rata laki-laki mengonsumsi air 1,5 liter cairan per hari sedangkan perempuan mengonsumsi air 1,6 liter per hari, konsumsi ini belum memenuhi jumlah yang dianjurkan yaitu 2 liter per hari atau setara dengan 8 gelas per hari. Oleh karena itu, penelitian ini memilih kelompok laki-laki di rentang umur remaja karena memiliki masalah konsumsi atau asupan cairan rendah yang berdampak pada dehidrasi. Pada penelitian ini, penentuan golongan usia muda bertujuan untuk menunjukkan bahwa secara fisiologis usia tersebut masih dalam fungsi-fungsi fisiologis yang normal sehingga penilaian dehidrasi tidak dipengaruhi oleh tingkatan umur, melainkan karena secara tidak disadari mereka telah mengalami dehidrasi akibat ketidakseimbangan cairan yang terus menerus (6). Kejadian dehidrasi pada wanita lebih tinggi daripada pria (7). Hal ini berhubungan dengan kecenderungan wanita memiliki proporsi jumlah air lebih sedikit karena proporsi lemak tubuh yang lebih banyak, selain itu faktor hormonal juga mempengaruhi status hidrasi pada wanita (8), oleh karena itu penelitian ini menggunakan subjek laki-laki dengan usia dewasa muda.

Kondisi dehidrasi juga dipengaruhi oleh aktivitas yang dilakukan oleh seseorang. Namun, pada penelitian ini aktivitas lain dari responden yang berupa kegiatan organisasi tidak memiliki hubungan yang signifikan dengan kondisi dehidrasi. Hal tersebut dapat diakibatkan 
adanya perbedaan intensitas dari kegiatan organisasi yang dilakukan oleh subjek penelitian. Selain itu, subjek penelitian merupakan mahasiswa dari berbagai macam fakultas yang memiliki kegiatan organisasi yang berbeda-beda. Penelitian yang dilakukan di Yogyakarta menunjukkan bahwa mahasiswa yang mengikuti jenis aktivitas organisasi yang berhubungan dengan aktivitas fisik memiliki kondisi hidrasi yang lebih baik sehingga risiko untuk mengalami dehidrasi menjadi 50\% lebih kecil dibandingkan subjek yang tidak berolahraga (9).

Berdasarkan hasil penelitian diketahui bahwa jenis kegiatan mahasiswa dan kebiasaan merokok tidak memiliki pengaruh signifikan terhadap kondisi dehidrasi ( $p>0,05)$. Penilaian dehidrasi dengan ortostatik pada atlet bukan merupakan alat ukur yang akurat. Kondisi jantung pada atlet cenderung baik sehingga pada saat dilakukan pengukuran ortostatik dapat dipastikan tidak ada masalah hidrasi yang ditemukan. Apabila dilihat dari kondisi ortostatik pada subjek yang berolahraga maka diketahui bahwa subjek dengan kebiasaan berolahraga memiliki kondisi tubuh yang mudah beradaptasi pada pengukuran uji ortostatik. Pada orang biasa akan mengalami kenaikan denyut jantung yang tinggi pada saat dilakukan pengukuran uji ortostatik dalam posisi berdiri. Sebaliknya pada orang dengan kebiasaan olahraga, kondisi tubuhnya akan cenderung lebih mudah menyesuaikan diri sehingga kenaikan denyut jantung pada saat posisi berdiri tidak terlalu tinggi. Adanya peningkatan denyut jantung pada pengukuran ortostatik ini juga diakibatkan adanya mekanisme hukum ohm dalam tubuh yaitu peningkatan denyut jantung akan menyebabkan peningkatan cardiac output yang biasanya juga disertai peningkatan stroke volume. Peningkatan denyut jantung menyebabkan peningkatan volume per menit curah jantung yang lebih sering diakibatkan oleh peningkatan denyut jantung dan stroke volume. Namun, peningkatkan curah jantung lebih sering terjadi karena meningkatnya denyut jantung (6).

Pengaturan hidrasi tubuh pertama kali adalah respon rasa haus. Penyebab rasa haus yang ditimbulkan dari dehidrasi adalah adanya sekresi anti-diuretika hormon (ADH) dan reseptor yang merupakan osmoreseptor dan sel saraf yang merespon baroreseptor kardiovaskular (10). Reseptor tersebut kemudian akan menginisiasi reflek pengendalian ADH melalui timbulnya rasa haus.
Penelitian yang dilakukan di Institute for Cardiovascular Research, University of Leeds, UK, diperoleh hasil bahwa latihan dalam intensitas sedang dapat meningkatkan toleransi ortostatik pada subjek penelitian yang memiliki aktivitas fisik rendah (11). Peningkatan toleransi ortostatik ini dihubungkan dengan kenaikan volume plasma serta penurunan sensitivitas baroreseptor. Berdasarkan penjelasan tersebut dapat disimpulkan bahwa seseorang dengan kegiatan olahraga rutin akan berisiko mengalami dehidrasi jika dilihat melalui pengukuran yang lain, misalnya dilihat dari urin atau kadar elektrolit dalam tubuh.

Hasil penelitian ini juga menunjukkan bahwa kebiasaan merokok tidak berhubungan dengan kejadian dehidrasi. Pengukuran dehidrasi dengan melihat tekanan darah tidak sensitif pada perokok, hal tersebut dapat diakibatkan oleh tidak adanya perbedaan tekanan darah yang signifikan antara subjek penelitian yang merokok dengan yang tidak merokok, baik tekanan darah sistolik $(\mathrm{p}=0,095)$ maupun tekanan darah diastolik $(\mathrm{p}=0,109)$. Namun demikian, merokok dapat mengakibatkan mulut terasa kering sehingga akan mengkonsumsi minuman lebih banyak untuk mengkompensasi rasa kering tersebut. Sesuai dengan penelitian yang dilakukan di Kerman Neuroscience Research Center, Kerman University of Medical Sciences, Iran menemukan hasil bahwa terdapat perbedaan signifikan mengenai salivary flow rate (SFR) pada perokok dan bukan perokok yaitu nilai SFR yang lebih besar pada subjek bukan perokok (12). Selain itu, dari penelitian tersebut diperoleh kesimpulan bahwa merokok dalam waktu yang lama akan mengurangi SFR. SFR yang berkurang ini dapat mengakibatkan mulut mudah kering dan meningkatkan risiko gangguan gigi dan mulut yang berkaitan dengan kondisi mulut kering. Namun, penelitian yang menunjukkan perbedaan asupan cairan pada perokok dan bukan perokok belum pernah dilakukan pengkajian lebih lanjut.

\section{SIMPULAN DAN SARAN}

Kasus dehidrasi di kalangan mahasiswa masih tinggi (60,9\%). Meskipun tidak ada hubungan antara aktivitas fisik dan kebiasaan merokok dengan dehidrasi, perlu dilakukan kajian mengenai konsumsi, jenis, jumlah asupan cairan, dan penilaian indikator hidrasi dengan menggunakan profil urin atau indikator lain yang lebih sensitif. 


\section{RUJUKAN}

1. Bennet JA, Thomas V, Riegel B. Unrecognized chronic dehydration in older adults: examining prevalence rate and risk factors. J Gerontol Nurs 2004;30(11):22-8.

2. Hardinsyah. $46,1 \%$ dari 1.200 penduduk Indonesia alami dehidrasi ringan. [series online] 2009 [cited 2010 Jun 12]. Available from: http://www.nusantaranews.com.

3. Marvin M, Julian MS, Sanjukta S, Arif M, Domenic S, William HF. Pathophysiology, diagnosis, and treatment of orthostatic hypotension and vasovagal syncope. Cardiol Rev 2008;16(1):4-20.

4. American Academy of Neurology. Consensus statement on the definition of orthostatic hypotension, pure autonomic failure and multiple system atrophy. Clin Auton Res 1996;6(2):125-6.

5. Coyle EF. Fluid and fuel intake during exercise. J Sports Sci 2004;22(1):39-55.

6. Schroeder C, Bush VE, Norcliffe Lj, Luft FC, Tank J, Jordan J, Hainsworth R. Water drinking acutely improve ortostatic tolerance in healthy subjects. Circulation 2002;106:2806-011.

7. Horne MM, Swearingen PL. Keseimbangan cairan, elektrolit dan asam basa. Jakarta: EGC; 2001.

8. Penggalih MHST, Tawarniarte MD, Sofro ZM. Poor water consumption lead to dehydration and orthostatic problem among college students. Proseding Seminar Nasional Peran Zat Gizi Air dalam Kehidupan Manusia; 2012 Oct 13; Yogyakarta. Yogyakarta: Fakultas Teknologi Pertanian UGM; 2012.

9. Chaudhuri SK. Concise medical physiology. Calcutta: New Central Book Agency; 2004.

10. Eaton DC, John PP. Vander's renal physiology. United States: The McGraw-Hill Companies, Inc; 2009.

11. Mtinangi BL, Hainsworth R. Effects of moderate exercise training on plasma volume, baroreceptor sensitivity and orthostatic tolerance in healthy subjects. Exp Physiol 1999;84(1);121-30.

12. Rad M, Kakoie S, Brojeni FN, Pourdamghan N. Effect long-term smoking on whole-mouth salivary flow rate and oral health. J Dent Res Dent Clin Dent Prospects 2010;4(4):110-4. 